\title{
Growing Characters of Proso millet (Panicum miliaceum L.) In Response to Different Rainwater Harvesting Practices in Semi-arid Region of the Loess Plateau in China
}

\author{
QU. Yang ${ }^{1,2}$, B. Feng ${ }^{1}$ \\ ${ }^{1}$ College of agronomy, Northwest $A$ \& F University, Yangling, Shaanxi, 712100, China \\ ${ }^{2}$ Baoji Institute of Agricultural Science, Qishan, Shaanxi, 722400, China
}

E-mail: 7012766@163.com

Received 16.01.2020 Accepted 07.02.2020

\begin{abstract}
In semi-arid and arid areas, crop growth is mainly limited by low rainfall (mm). Using plastic film-mulched and special soil tillage can be employed to harvest limited rainfall for crop growth so as to assure food production. The objective of this work was to find out how to exploit limited rainfall $(\mathrm{mm})$ to increase yield of proso millet. Effects of different rainfall harvesting systems based on plastic film-mulched in proso millet were managed in semi-arid regions of Loess Plateau in 2010-2012, and soil type that study involved was calciccambisols. The hypothesis was that proso millet could improve growth and yield of proso millet by using rainfall harvesting system. Experiment designed three rainfall harvesting systems based on plastic mulched and no mulching (NM) as a control. A flat plot with no mulching was a control (NM), the width of furrow was $60 \mathrm{~cm}$ with $60 \mathrm{~cm}$ wide ridge (P60), the width of furrow was 60 $\mathrm{cm}$ with $100 \mathrm{~cm}$ wide M-shaped ridge (M160), and the width of furrow was $40 \mathrm{~cm}$ with $40 \mathrm{~cm}$ wide W-shaped ridge (W80). Control plot and systems were laid out in a randomized block design with three replications. Only the ridge was mulched with white plastic film. The results showed as follows: rainfall harvesting systems based on plastic film-mulched could increase water content of topsoil by $19.6 \%-43 \%$, move up in temperature of topsoil by $0.1^{\circ} \mathrm{C}-2.7^{\circ} \mathrm{C}$, improve agronomic traits $(\mathrm{P}<0.05)$, and increase yield by 96.8\%-115.3\% ( $P<0.05)$ and WUE by $120.2 \%-179.3 \%(P<0.05)$ compared with those of NM, respectively; "W-shaped" system performed advantage enough among all rainfall harvesting systems, increased water content of topsoil and temperature of topsoil, and separately increased yield and WUE of proso millet by $115.3 \%$ and $179.3 \%$ compared with those of $N M(P<0.05)$ in three growing seasons; average rate of yield increase of proso millet in all rainfall harvesting systems tended to be quadratic function correlated with the rainfall $(\mathrm{mm})\left(\mathrm{R}^{2}=1\right)$; rainfall harvesting systems had better effect on improving plant heights at early growing stage of proso millet than those at later growing stage. The hypothesis was supported by these findings that suggested rainfall harvesting systems with plastic film-mulched could improve yield and water use efficiency of proso millet and have affection effectively at early growing stage of proso millet, increasing yield of rainfall harvesting system was limited by abundant rainfall $(\mathrm{mm})$ and had to be suitable for $250 \mathrm{~mm}-300 \mathrm{~mm}$ rainfall of growing seasons for proso millet; "W-shaped" system performed well in semi-arid areas.
\end{abstract}

Keywords: rainfall saving technology; ridge-furrow tillage; rain-fed areas

\section{Introduction}

Proso millet (Panicum miliaceum L.) is an important food crop in semi-arid region of the Loess plateau (Zhang et al., 2012), still yield of proso millet remains low under rain-fed agriculture conditions because rainfall is not adequate to meet evaporation requirement during growing seasons (Jaetzold $\mathrm{R}$ et al., 2006; Xie et al., 2010; Li et al., 2013).

To increase yield of proso millet and ensure food supply in dry-land areas, rainfall harvesting technology for planting proso millet is necessary for practicing. Conservation agriculture is very helpful in maintaining soil moisture level through the use of cover crops and crop residue mulch retention (Derpsch, 2005; Hobbs, 2007), provides weed control and yield benefits (Murungu et al., 2010; Musunda, 2010; E. Dube et al., 2012 ), improves economic characters of crops (Zentner et al., 2002) and soil organic matter (Zentner et al., 2004), and increases yield (Lafond et al., 1996; Chen et al., 2011), respectively. Whereas this technique has uncertain yield (Mahli et al., 1988; Canarache and Dumitru, 2008; Xie et al., 2008) that depends on soil type (Tolk et al., 1999), climate (Lampurlanes et al., 2002), and land slope (Zhang et al., 2009). Besides, a mulching technique with mixed sand and gravel adopted in the northwestern regions has great effects on reducing evaporation and runoff, improving water infiltration, increasing soil temperature, maintaining soil water and fertility (Gale et al., 1993; Modaihsh et al., 1985; Van wesemael et al., 1996; Nachtergaele et al., 1998; Xie et al., 2010, 2006), but quite high construction cost renders sand-gravel mixture mulch technique to use on a commercial scale difficult (Wang et al., 2004b; Yajun et al., 2011). Mulching practices with plastic film is introduced in 1978 and has spread quickly and widely, especially in rain-fed regions because it makes limited rainfall utilized effectively (Dong et al., 2009), endures water lost under evaporation (Liakatas et al.,1986; Muller, 1991), redistributes moisture in the soil, alleviates water stress to some extent (Li et al., 2004), and keeps topsoil warmer and moist (Li et al., 2001, 1999; Song et al., 2002; Wang et al., 2003), respectively. Meanwhile, plastic film-mulched improved rate of photosynthesis (Li et al., 1999) and roots growth of crops 
(Li et al., 2004b), therefore plastic film-mulched can increase crops yield (Ramakrishna et al., 2006; Luis Ibarra-Jimenez et al., 2011), water use efficiency (Tian et al., 2003; Zhou et al., 2009), and economic return (Chakraborty et al., 2008).

Currently, rainfall harvesting system is feasible alternatives for rain-fed agricultural production (Majed and Abdullah, 2011), and this system with furrows and plastic film-mulched ridges was effective farming practice that was used to solve problems of water shortages over many years in arid and semi-arid regions (Zhu et al.,1994; Zhao et al., 1995; Gao et al., 2008). Rainfall harvesting system with furrows and plastic film-mulched ridges was more effective on improving crop production (Lal et al., 1984; Wang et al., 2013). Li et al. (2001) reported that plastic mulched ridge and furrow rainfall harvesting (PRFRH) system improved water efficiency and increased maize yield over the bare ridge and furrow rainfall harvesting (RFRH) system under semiarid conditions in northwest China. Rainfall harvesting system with furrows and plastic film-mulched ridges can be an optimal practice to improve runoff efficiency, rainwater harvesting, crop yield, water use efficiency (WUE) (Li et al., 2000; Zhang et al., 2006; Wang et al., 2009), and produce greater economic benefit than conventional cultivation (Zhou et al., 2009; Liu et al., 2009; Shuhuai et al., 2012).

In recent years, despite the effects of rainfall harvesting systems on proso millet are yet be reported in semi-arid areas of north China (Qu et al., 2012), the objective of this study was to explore optimum rainfall harvesting systems in proso millet, including valid stage and limiting factor of rainfall harvesting system. The hypotheses of this study were that (a) rainfall harvesting systems could increase water content of topsoil and temperature of topsoil and improve proso millet growth, yield and WUE; (b) rainfall harvesting systems took effect at the early stage of proso millet; (c) rainfall harvesting system performed well depended on rainfall $(\mathrm{mm})$.

\section{Study area and data analysis}

\section{Study site description}

Rainfall harvesting systems with furrows and plastic film-mulched ridges were conducted at Canghemao Experimental Station, Northwest A \& F university, Fugu, Shaanxi province $\left(39.09^{\circ} \mathrm{N}, 111.01^{\circ} \mathrm{E}\right.$ and altitude $\left.1000 \mathrm{~m}\right)$ during $2010-2012$ seasons. The study site is dry-land regions with annual mean precipitation of $366.2 \mathrm{~mm}$; a mean annual temperature is $9.1^{\circ} \mathrm{C}$ with a maximum of $38.9^{\circ} \mathrm{C}$ and a minimum of $-24^{\circ} \mathrm{C}$; an average annual pan evaporation of $1092.2 \mathrm{~mm}$; an average annual sunshine duration of $2890 \mathrm{~h}$ and a frost-free period of over 177 frost-free days. Soil type is calciccambisols whose properties at each depth were showed in table 1. Analysis of the topsoil $(0-20 \mathrm{~cm})$ obtained the following results: an organic C content of $19.32 \mathrm{~g} \mathrm{~kg}^{-1}$, a nitrate N content of $1.2 \mathrm{~g}$ $\mathrm{kg}^{-1}$, an available $\mathrm{P}$ content of $6.4 \mathrm{mg} \mathrm{kg}^{-1}$, an available $\mathrm{K}$ content of $89 \mathrm{mg} \mathrm{kg}^{-1}$, an ammonium N$\left(\mathrm{NH}^{+}+\mathrm{NO}^{-}\right)$content of $44.3 \mathrm{mg}$ $\mathrm{kg}^{-1}$, and a soil bulk density of $1.50 \mathrm{~g} \mathrm{~cm}^{-3}$.

Table 1. Properties of the different soil layers at the experimental site.

\begin{tabular}{|c|c|c|c|c|}
\hline $\begin{array}{l}\text { Soil layer depth } \\
(\mathrm{cm})\end{array}$ & $\begin{array}{l}\text { Soil bulk density } \\
\left(\mathrm{g}^{\prime} \mathrm{cm}^{-3}\right)\end{array}$ & Soil porosity & $\begin{array}{l}\text { Wilting coefficient } \\
\left(g^{\cdot} \mathbf{k g}^{-1}\right)\end{array}$ & $\begin{array}{l}\text { Field capacity } \\
\left(\mathrm{g}^{\cdot} \mathbf{k g}^{-1}\right)\end{array}$ \\
\hline $0-20$ & 1.50 & 0.43 & 25 & 48 \\
\hline $40-60$ & 1.63 & 0.39 & 27 & 51 \\
\hline $60-80$ & 1.62 & 0.39 & 26 & 49 \\
\hline
\end{tabular}

\section{Experimental design}

In this study, three rainfall harvesting systems were designed as follows: the width of furrow was $60 \mathrm{~cm}$ with $60 \mathrm{~cm}$ wide ridge (P60) (Figure 1), the width of furrow was $60 \mathrm{~cm}$ with $100 \mathrm{~cm}$ wide M-shaped ridge (M160) (Figure 2), and the width of furrow was $40 \mathrm{~cm}$ with $40 \mathrm{~cm}$ wide W-shaped ridge (W80) (Figure 3). A flat plot with no mulching (NM) is as a control. Plots of P60, M160 and W80 with areas of $4.8 \times 5 \mathrm{~m}^{2}, 6.4 \times 5 \mathrm{~m}^{2}$ and $3.2 \times 5 \mathrm{~m}^{2}$ were composed of four ridges and furrows alternately. Plot of NM had an area of $3.2 \times 5 \mathrm{~m}^{2}$. All systems and control plot had three replications that were arranged in a randomized block design, and buffer row between treatments was 1 row. Ridges of P60, M160, and W80 were covered with $0.008 \mathrm{~mm}$ white plastic film (Height: $10 \mathrm{~cm}$ ), and both ends of plastic film were perpendicular to furrow surface and embedded in soil (Depth: $5 \mathrm{~cm}$ ). The entire experimental area was ploughed after all fertilizers (34.5 N kg ha-1, 9.0 P2O5 kg ha ${ }^{-1}$ ) were incorporated into the soil surface (Plough depth: 20 $\mathrm{cm}$ ) according to conventional fertilizing method. The cultivar "Yumi $2^{\prime \prime}$ of proso millet with density of $5.0 \times 105$ plants ha" ${ }^{-1}$ were sown on 11 June and harvested on 25 September in 2010, sown on 12 June and harvested on 23 September in 2011, and sown on 15 June and harvested on 27 September in 2012, respectively.

$$
\text { Proso millet Proso millet Proso millet }
$$

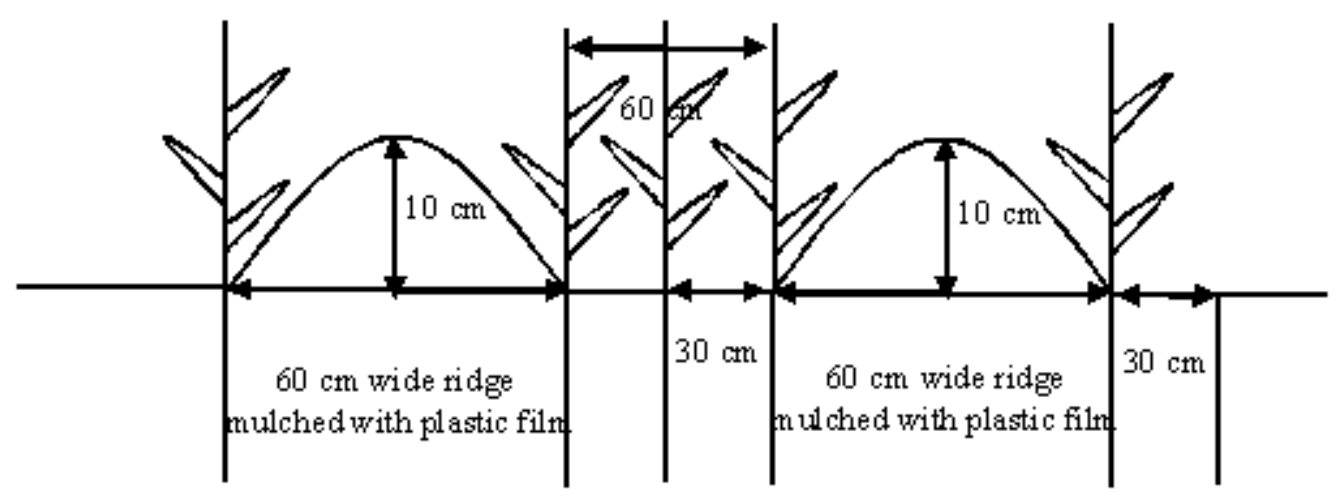

Figure 1. P60, the rainwater harvesting practice with $60 \mathrm{~cm}$ wide ridges mulched with plastic film. 


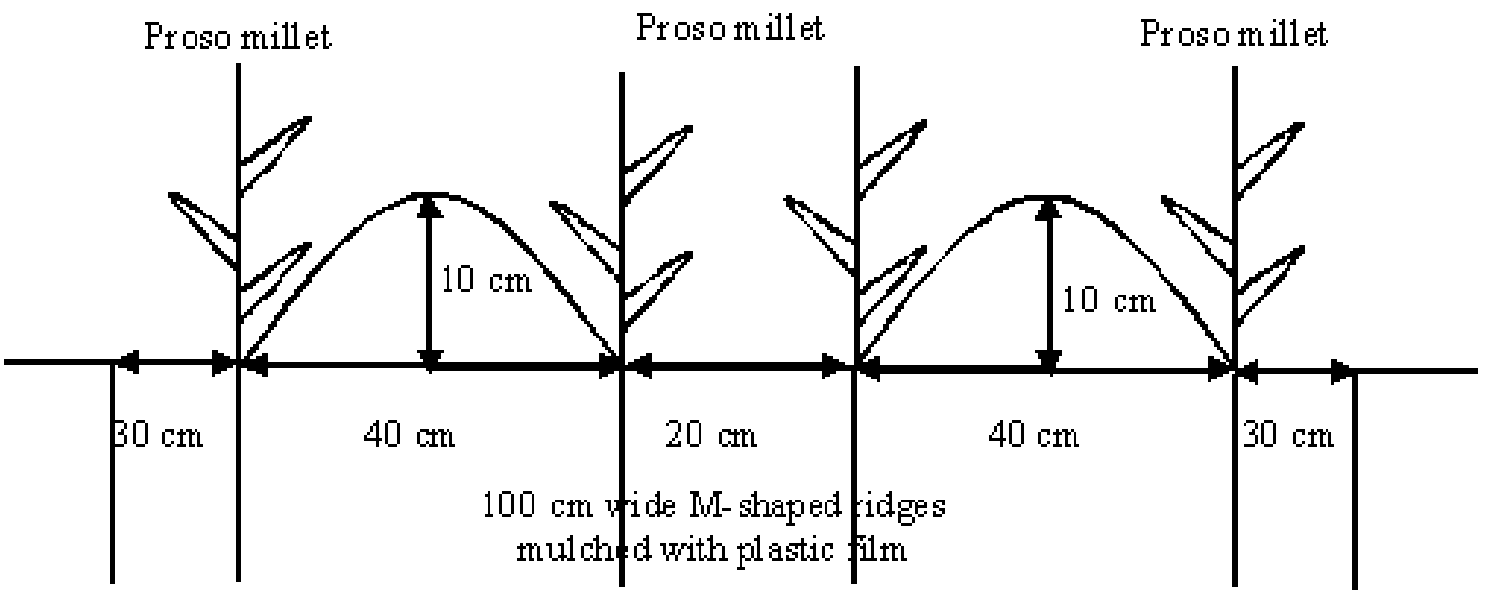

Figure 2. M160, the rainwater harvesting practice with $100 \mathrm{~cm}$ wide M-shaped ridges mulched with plastic film.

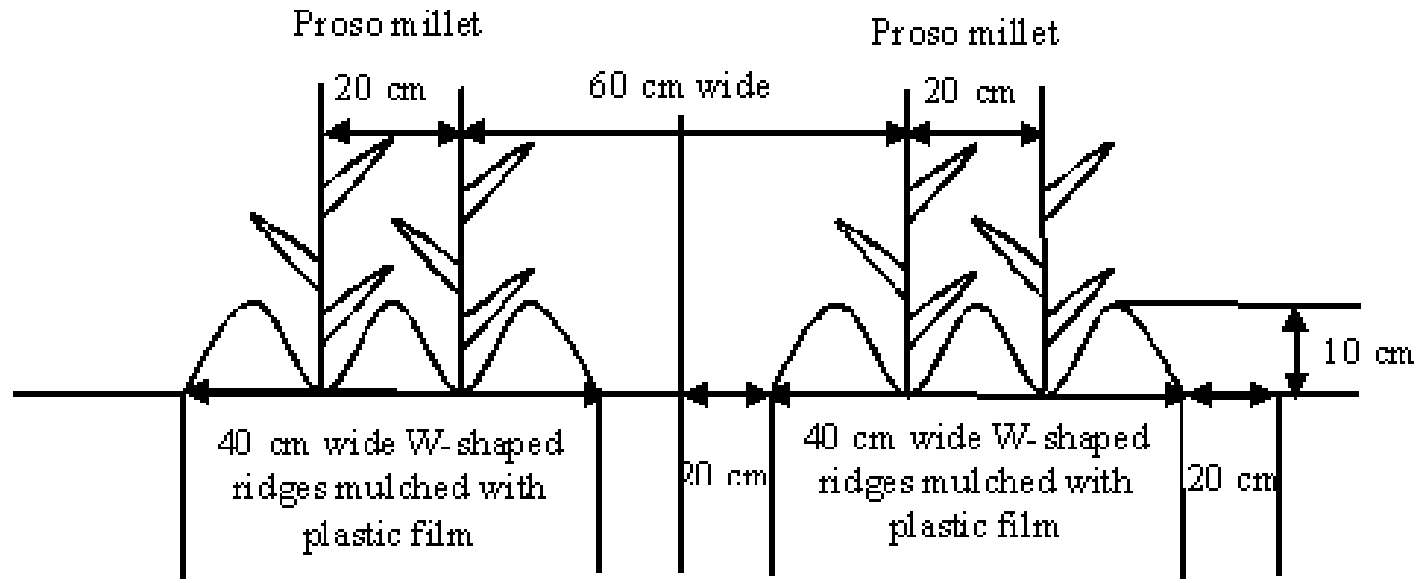

Figure 3. W80, the rainwater harvesting practice with $40 \mathrm{~cm}$ wide $\mathrm{W}$-shaped ridges mulched with plastic film.

\section{Sampling and measurements}

Soil temperature at $10 \mathrm{~cm}$ soil layer was recorded in planting furrow of P60, M160, W80 and NM every two weeks until 60 days after sowing and the 10: 00 reading in the morning.

The water content in $0-100 \mathrm{~cm}$ soil profile was determined at depth intervals of $20 \mathrm{~cm}$. Measurements were made approximately every two weeks during the growing seasons of proso millet. Soil water storage in the profile was considered to be the total storage (0-100 cm). Crop evapotranspiration $\left(E_{c}\right)$ was determined using the formula (Zhang et al., 2011):

$$
\mathrm{ET}_{\mathrm{c}}=\mathrm{P}+\mathrm{SW}_{\mathrm{p}}-\mathrm{SW}_{\mathrm{h}}+\mathrm{I}-\mathrm{R}-\mathrm{D}
$$

In which, $\mathrm{P}$ is the precipitation ( $\mathrm{mm}$ ) during the crop growth season; SWp is soil water storage (mm) at planting stage based on mean value of furrow and ridge; SWh is soil water storage $(\mathrm{mm})$ at harvesting stage based on mean value of furrow and ridge; I is the amount of irrigation $(\mathrm{mm})$, which was negligible due to no irrigation in this study site; $\mathrm{R}$ is surface runoff that was negligible due to barriers separating the plots that blocked runoff along furrows and ridges of rainfall harvesting systems; $D$ is the amount of water lost due to deep drainage $(\mathrm{mm})$ that was negligible due to $30 \mathrm{~m}$ deep water layer and less rainfall (Wang et al., 2004a).

Water use efficiency (WUE) of proso millet was calculated as grain yield (GY) in $\mathrm{t} \mathrm{ha}^{-1}$ divided by total water use in mm (Evaluated as $\mathrm{ET}_{\mathrm{c}}$ in the present study):

\section{Data analysis}

$$
\mathrm{WUE}=\mathrm{GY} / \mathrm{ET}_{\mathrm{C}}
$$

All data were analyzed by SAS V6 and Microsoft Excel 2003 software, and mean values were compared by Duncan' method $(P<0.05)$.

\section{Results}

\section{Soil water}

The water content of topsoil with different systems is showed in table 2. At jointing stage and mature stage, water contents of topsoil of different systems were higher than those of NM in three growing seasons. At jointing stage, water content of topsoil of different systems increased by $16.2 \%, 23.8 \%$, and $40.4 \%$, respectively in 0-20 cm soil layer compared with those of NM in three growing seasons. At mature stage, water content of topsoil of different systems increased by $15.4 \%$, $15.4 \%$, and $34.9 \%$, respectively in $0-20 \mathrm{~cm}$ soil compared with those of NM in three growing seasons. In $20-40 \mathrm{~cm}$ soil layer, water content of topsoil of different systems increased by $21.1 \%, 32.7 \%$, and $44.3 \%$, respectively compared with those of NM at jointing stage in three growing seasons, and water contents of topsoil of different systems increased by $14.7 \%, 32.5 \%$, and $45.1 \%$, respectively compared with those of NM at mature stage in the three growing seasons. In $0-40 \mathrm{~cm}$ topsoil layer, water content of soil of different systems increased by $19.6 \%, 30 \%$, and $43 \%$, respectively compared with those of NM at jointing stage and increased by $15.2 \%, 26.8 \%$, and $41.8 \%$, respectively at mature stage compared with those of NM in three growing seasons. 
Table 2. Water contents of topsoil with the different rainwater harvesting and NM practices at the jointing and mature stages in 2010-2012 (Mean (mm) \pm SD). W80, the rainwater harvesting practice with $40 \mathrm{~cm}$ wide plastic film mulched W-shaped ridges; M160, the rainwater harvesting practice with $100 \mathrm{~cm}$ wide plastic film mulched M-shaped ridges; P60, the rainwater harvesting practice with $60 \mathrm{~cm}$ wide plastic film mulched ridges; NM, non-mulching plots.

\begin{tabular}{|c|c|c|c|c|c|c|c|c|c|c|}
\hline \multirow{2}{*}{ Year } & \multirow{2}{*}{$\begin{array}{l}\text { Soil } \\
\text { depth } \\
(\mathrm{cm})\end{array}$} & \multirow[t]{2}{*}{ layer } & \multicolumn{4}{|c|}{ Jointing stage } & \multicolumn{4}{|c|}{ Mature stage } \\
\hline & & & NM & P60 & M160 & W80 & NM & P60 & M160 & W80 \\
\hline \multirow{2}{*}{2010} & $0-20$ & & $\begin{array}{l}14.7 \pm 0 \\
7\end{array}$ & $16.5 \pm 0.8$ & $18.3 \pm 0.9$ & $20.7 \pm 1.2$ & $\begin{array}{l}14.1 \pm 1 . \\
0\end{array}$ & $\begin{array}{l}17.5 \pm 1 \\
0\end{array}$ & $\begin{array}{l}23.9 \pm 1 . \\
2\end{array}$ & $\begin{array}{l}26.0 \pm 0 . \\
9\end{array}$ \\
\hline & $20-40$ & & $\begin{array}{l}30.6 \pm 1 \\
2\end{array}$ & $34.6 \pm 1.0$ & $42.0 \pm 2.1$ & $42.0 \pm 2.1$ & $\begin{array}{l}22.8 \pm 1 . \\
1\end{array}$ & $\begin{array}{l}33.0 \pm 2 . \\
0\end{array}$ & $\begin{array}{l}41.6 \pm 1 \\
7\end{array}$ & $\begin{array}{l}42.8 \pm 2 . \\
7\end{array}$ \\
\hline \multirow{2}{*}{2011} & $0-20$ & & $\begin{array}{l}18.7 \pm 0 . \\
9\end{array}$ & $20.1 \pm 1.0$ & $22.1 \pm 1.1$ & $23.0 \pm 1.2$ & $\begin{array}{l}10.7 \pm 0 \\
7\end{array}$ & $\begin{array}{l}12.0 \pm 0 . \\
6\end{array}$ & $\begin{array}{l}12.2 \pm 0 . \\
3\end{array}$ & $\begin{array}{l}18.6 \pm 1 . \\
2\end{array}$ \\
\hline & $20-40$ & & $\begin{array}{l}41.9 \pm 2 . \\
1\end{array}$ & $46.3 \pm 3.2$ & $54.3 \pm 2.7$ & $57.5 \pm 2.9$ & $\begin{array}{l}24.7 \pm 1 . \\
1\end{array}$ & $\begin{array}{l}25.1 \pm 1 . \\
6\end{array}$ & $\begin{array}{l}27.6 \pm 1 \\
4\end{array}$ & $\begin{array}{l}30.6 \pm 1 . \\
8\end{array}$ \\
\hline \multirow{2}{*}{2012} & $0-20$ & & $\begin{array}{l}37.0 \pm 1 . \\
9\end{array}$ & $45.4 \pm 2.3$ & $46.9 \pm 2.3$ & $55.1 \pm 2.1$ & $\begin{array}{l}27.6 \pm 1 . \\
6\end{array}$ & $\begin{array}{l}31.0 \pm 1 . \\
8\end{array}$ & $\begin{array}{l}24.5 \pm 1 . \\
0\end{array}$ & $\begin{array}{l}26.1 \pm 1 . \\
7\end{array}$ \\
\hline & $20-40$ & & $\begin{array}{l}90.8 \pm 3 . \\
6\end{array}$ & $\begin{array}{l}116.8 \pm 4 . \\
7\end{array}$ & $\begin{array}{l}120.3 \pm 8 \\
6\end{array}$ & $\begin{array}{l}135.9 \pm 11 . \\
2\end{array}$ & $\begin{array}{l}50.2 \pm 3 . \\
3\end{array}$ & $\begin{array}{l}54.3 \pm 4 . \\
5\end{array}$ & $\begin{array}{l}60.5 \pm 2 . \\
9\end{array}$ & $\begin{array}{l}68.7 \pm 2 . \\
4\end{array}$ \\
\hline \multirow{3}{*}{$\begin{array}{l}\text { Mean over the } \\
3 \quad \text { experiment } \\
\text { years }\end{array}$} & $0-20$ & & 23.5 & 27.3 & 29.1 & 33.0 & 17.5 & 20.2 & 20.2 & 23.6 \\
\hline & $20-40$ & & 54.4 & 65.9 & 72.2 & 78.5 & 32.6 & 37.4 & 43.2 & 47.3 \\
\hline & $0-40$ & & 77.9 & 93.2 & 101.3 & 111.4 & 50.0 & 57.6 & 63.4 & 70.9 \\
\hline
\end{tabular}

\section{Soil temperature}

Soil temperature in $\mathbf{0 - 1 0} \mathrm{cm}$ soil layer is showed in Figure 4 during the proso millet growing seasons. Soil temperatures of different systems and NM were higher than air temperature in three growing seasons. Mean soil temperature of different systems were $0.2^{\circ} \mathrm{C}, 2.1^{\circ} \mathrm{C}$, and $2.2^{\circ} \mathrm{C}$ higher than those of $\mathrm{NM}$ at 15 days after sowing in three growing seasons, respectively. Mean soil temperature of different systems increased by $0.3^{\circ} \mathrm{C}, 2.6^{\circ} \mathrm{C}$, and $2.7^{\circ} \mathrm{C}$ compared with those of NM at 30 days after sowing in three growing seasons, respectively. Mean soil temperatures of different systems were $0.1^{\circ} \mathrm{C}, 2.1^{\circ} \mathrm{C}$, and $1.8^{\circ} \mathrm{C}$ higher than those of NM at 45 days after sowing in the three growing seasons, respectively, and mean soil temperatures of different systems were $0.6^{\circ} \mathrm{C}$, $2.4^{\circ} \mathrm{C}$, and $2.6^{\circ} \mathrm{C}$ higher than those of NM at 60 days after sowing in three growing seasons, respectively.

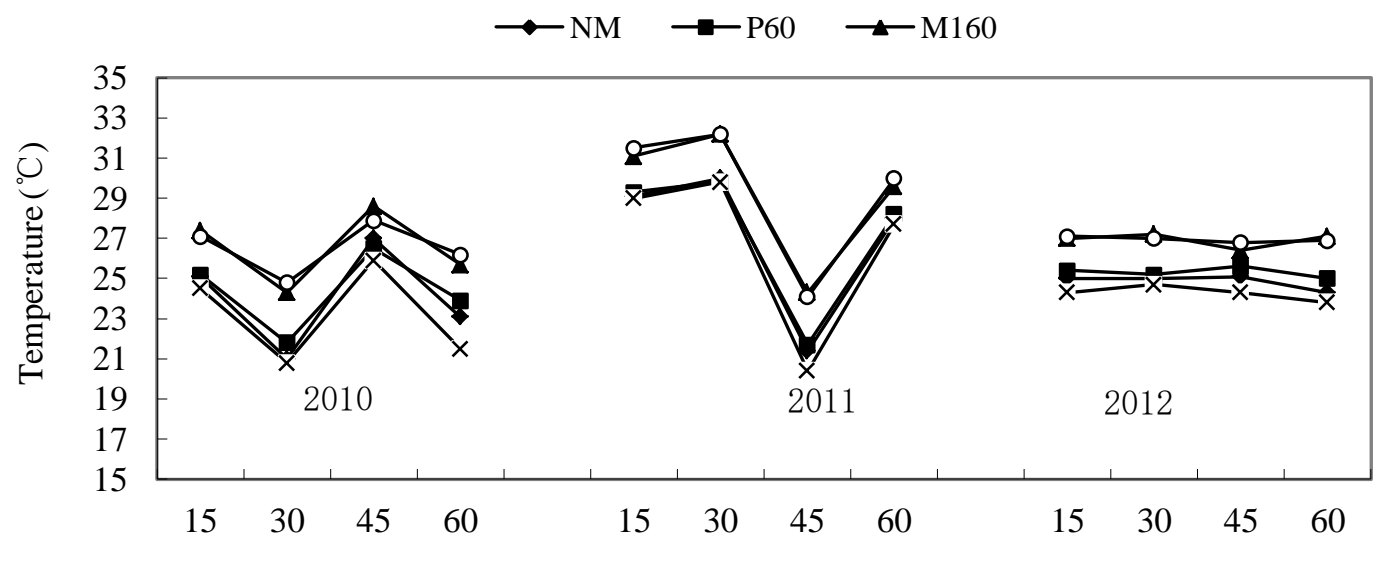

Days after planting $(d)$

Figure 4. Topsoil temperatures $(0-10 \mathrm{~cm}$ soil) with the different rainwater harvesting and NM practices in the growing seasons of proso millet from 2010 to 2012 . W80, the rainwater harvesting practice with $40 \mathrm{~cm}$ wide plastic film mulched W-shaped ridges; M160, the rainwater harvesting practice with $100 \mathrm{~cm}$ wide plastic film mulched M-shaped ridges; P60, the rainwater harvesting practice with $60 \mathrm{~cm}$ wide plastic film mulched ridges; NM, non-mulching plots; Air, surface air.

\section{Agronomic traits}

\section{Plant height}

Plant heights of rainfall harvesting systems are showed in Figure 5. Plant heights of rainfall harvesting systems were significant difference from those of NM $(\mathrm{P}<0.05)$ in three growing seasons. Plant heights of rainfall harvesting systems at jointing stage increased by $44.7 \%, 42.2 \%$, and $43.2 \%$ in 2010 , by $11.6 \%, 15.8 \%$, and $20.2 \%$ in 2011 , then by $8.5 \%, 20.5 \%$, and $19.3 \%$ in 2012 compared with those of NM, respectively. Average plant heights based on different rainfall harvesting systems increased by $21.6 \%, 26.2 \%$, and $25.7 \%$ at jointing stage in three growing seasons compared with those of NM, respectively.

At mature stage, plant heights of different rainfall harvesting systems increased by $4.1 \%, 14.7 \%$, and $11.3 \%$ in 2010 , by $14.2 \%$, $10.0 \%$, and $10.2 \%$ in 2011 , then by $4.2 \%, 11.9 \%$, and $10.7 \%$ in 2012 compared with those of NM, respectively. Mean plant heights of rainfall harvesting systems increased by $7.5 \%, 12.2 \%$, and $10.7 \%$ compared with those of NM at mature stage in three growing seasons, respectively. 


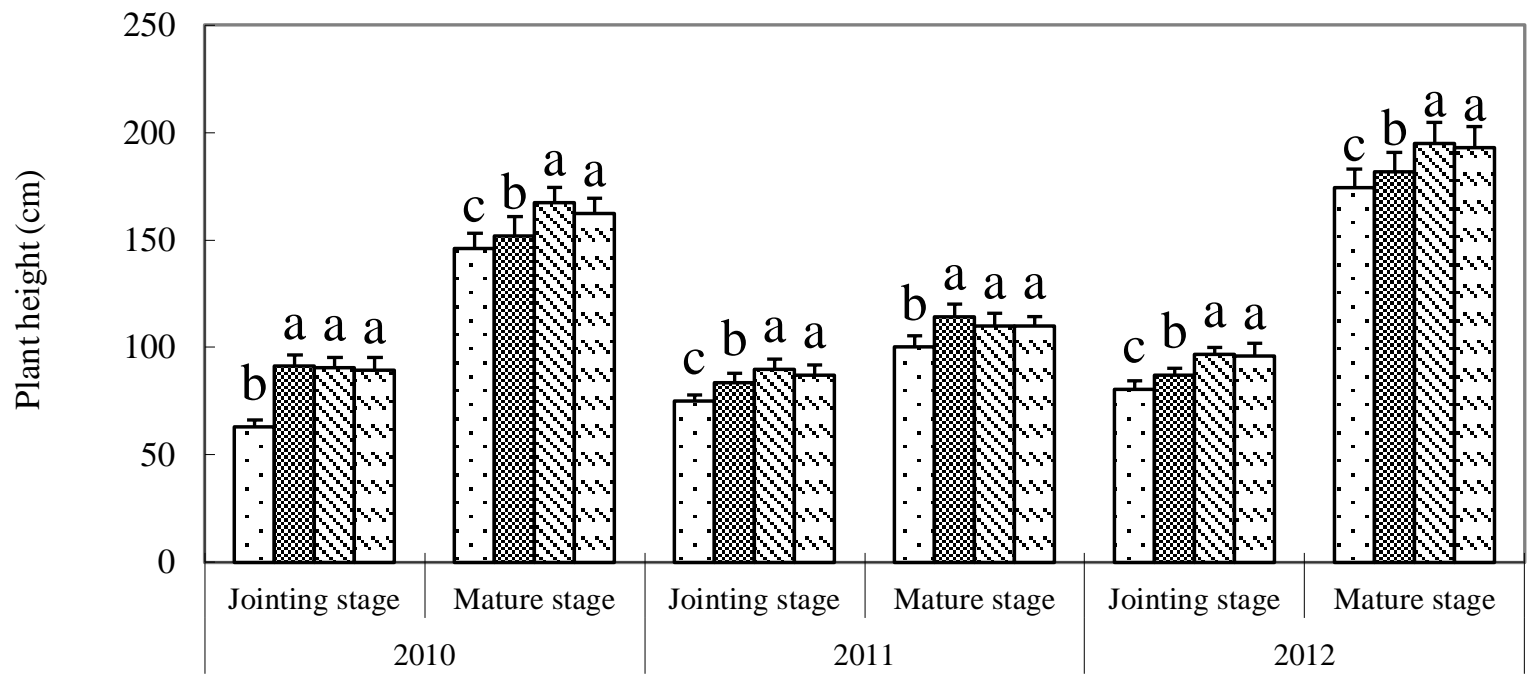

Figure 5. Plant heights with the different rainwater harvesting and NM practices at the jointing stage and mature stages. W80, the rainwater harvesting practice with $40 \mathrm{~cm}$ wide plastic film mulched W-shaped ridges; M160, the rainwater harvesting practice with $100 \mathrm{~cm}$ wide plastic film mulched M-shaped ridges; P60, the rainwater harvesting practice with $60 \mathrm{~cm}$ wide plastic film mulched ridges; NM, non-mulching plots.

\section{Yield traits}

Agronomic traits of yield of proso millet under different rainfall harvesting systems are showed in table 3. In three growing seasons, panicle lengths and branches were difference $(P<0.05)$ between rainfall harvesting systems and NM, while No. of main stem and 1000 -seed weights was not difference in three growing seasons.

Table 3. Agronomic traits with the different rainwater harvesting and NM practices in 2010-2012 (mean \pm SD). W80, the rainwater harvesting practice with $40 \mathrm{~cm}$ wide plastic film mulched W-shaped ridges; M160, the rainwater harvesting practice with $100 \mathrm{~cm}$ wide plastic film mulched M-shaped ridges; P60, the rainwater harvesting practice with $60 \mathrm{~cm}$ wide plastic film mulched ridges; NM, non-mulching plots. In the same year, different lowercase letters in the same columns indicate significant differences at $p=0.05$.

\begin{tabular}{|c|c|c|c|c|c|}
\hline Year & Treatment & $\begin{array}{l}\text { Node number } \\
\text { of main stem } \\
\text { (ea) }\end{array}$ & $\begin{array}{l}\text { Panicle length } \\
(\mathrm{cm})\end{array}$ & $\begin{array}{l}\text { Number of } \\
\text { panicle branch } \\
\text { (ea) }\end{array}$ & $\begin{array}{l}\text { 1000-grain } \\
\text { weight } \\
\text { (g) }\end{array}$ \\
\hline \multirow{3}{*}{2010} & P60 & $7.4 \pm 0.5 a$ & $35.0 \pm 2.0 \mathrm{a}$ & $14.5 \pm 0.8 \mathrm{a}$ & $9.2 \pm 0.4 a$ \\
\hline & M160 & $7.5 \pm 0.4 a$ & $35.6 \pm 1.8 a$ & $14.7 \pm 0.9 a$ & $9.2 \pm 0.5 a$ \\
\hline & NM & $7.4 \pm 0.3 a$ & $33.5 \pm 1.7 b$ & $12.7 \pm 0.4 b$ & $9.1 \pm 0.5 a$ \\
\hline \multirow{2}{*}{2011} & M160 & $6.5 \pm 0.3 a$ & $34.4 \pm 1.8 \mathrm{a}$ & $15.1 \pm 0.8 \mathrm{a}$ & $8.9 \pm 0.7 a$ \\
\hline & NM & $6.4 \pm 0.4 a$ & $32.3 \pm 1.4 \mathrm{c}$ & $13.4 \pm 0.6 c$ & $8.9 \pm 0.7 a$ \\
\hline \multirow{2}{*}{2012} & P60 & $3.0 \pm 0.1 \mathrm{a}$ & $43.3 \pm 2.4 c$ & $7.7 \pm 0.4 a$ & $8.6 \pm 0.4 a$ \\
\hline & W80 & $3.0 \pm 0.2 \mathrm{a}$ & $46.3 \pm 2.0 \mathrm{a}$ & $7.7 \pm 0.5 \mathrm{a}$ & $8.6 \pm 0.4 a$ \\
\hline
\end{tabular}

Yield of proso millet showed that rainfall harvesting systems had more significant effects on increasing yield of proso millet than those of NM $(P<0.05)$ (table 4). In 2010, the rates of increase of yield under different rainfall harvesting systems were $1392 \mathrm{~g} \mathrm{~kg}^{-1}$, $1719 \mathrm{~g} \mathrm{~kg}^{-1}$, and $1494 \mathrm{~g} \mathrm{~kg}^{-1}$ compared with those of NM, respectively; In next growing season, the rates of increase of yield of proso millet under different rainfall harvesting systems were $1327 \mathrm{~g} \mathrm{~kg}^{-1}, 1503 \mathrm{~g} \mathrm{~kg}^{-1}$, and $1383 \mathrm{~g} \mathrm{~kg}^{-1}$ compared with those of NM, respectively; In 2012, the rates of yield increased under different rainfall harvesting systems were $185 \mathrm{~g} \mathrm{~kg}^{-1}, 238 \mathrm{~g} \mathrm{~kg}{ }^{-1}$, and $229 \mathrm{~g}$ $\mathrm{kg}^{-1}$ compared with those of NM, respectively. Yield of different rainfall harvesting systems increased by $968 \mathrm{~g} \mathrm{~kg}^{-1}$, $1153 \mathrm{~g} \mathrm{~kg}^{-1}$, and $1035 \mathrm{~g} \mathrm{~kg}^{-1}$ compared with those of NM in three growing seasons, respectively. "W-shaped" system performed best among rainfall harvesting systems and the yield of proso millet with this system increased by $238 \mathrm{~g} \mathrm{~kg}^{-1}-1719 \mathrm{~g} \mathrm{~kg}^{-1}$ compared with those of NM and mean rate of yield increase was $1153 \mathrm{~g} \mathrm{~kg}^{-1}$.

\section{WUE}

Water use efficiency under different rainfall harvesting systems significant differed with those of NM in three growing seasons (table 4) $(\mathrm{P}<0.05)$. In 2010, WUE of different systems increased by $180.0 \%, 250 \%$, and $214 \%$ compared with those of NM, respectively; WUE of different systems increased by $142.3 \%, 223.1 \%$, and $188.5 \%$ compared with those of NM in next growing season, respectively; WUE of different systems increased by $38.7 \%, 65.3 \%$, and $52.0 \%$ compared with those of NM in 2012 , 
respectively. Mean WUE of different rainfall harvesting systems increased by $120.2 \%, 179.3 \%$, and $152.1 \%$ compared with those of NM in three growing seasons, respectively. "W-shaped" system performed best in terms of WUE among different rainfall harvesting systems, and WUE with "W-shaped" system increased by $65.3 \%-250 \%$ in three growing seasons as well as mean rate of WUE increase was $179.3 \%$.

Table 4. Water use efficiencies with the different rainwater harvesting and NM practices in 2010-2012 (mean \pm SD). W80, the rainwater harvesting practice with $40 \mathrm{~cm}$ wide plastic film mulched W-shaped ridges; M160, the rainwater harvesting practice with $100 \mathrm{~cm}$ wide plastic film mulched M-shaped ridges; P60, the rainwater harvesting practice with $60 \mathrm{~cm}$ wide plastic film mulched ridges; NM, non-mulching plots. In the same year, different lowercase letters in the same columns indicate significant differences at $p=0.05$.

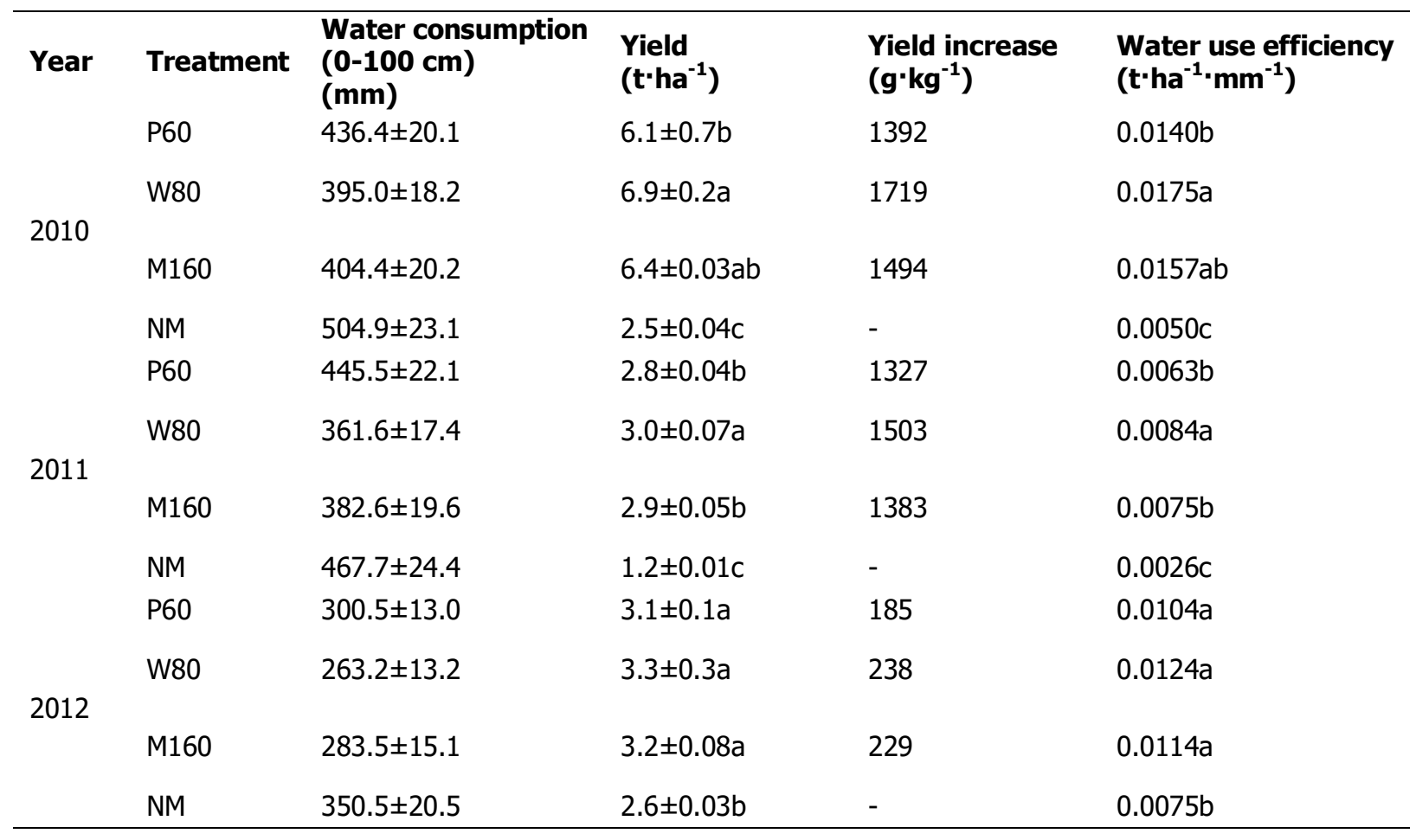

\section{Yield and rainfall}

Yield of proso millet with different rainfall harvesting systems at the rainfall $(\mathrm{mm})$ in three growing seasons are showed in Figure 6. Yield of rainfall harvesting system moved up with rainfall $(\mathrm{mm})$ increase in 2010-2011. However, low yield of rainfall harvesting systems were found in 2012 due to lodging. Rainfall $(\mathrm{mm})$ was different in three growing seasons, still yield of proso millet with different rainfall harvesting systems were higher than those of NM. Average yield of proso millet of rainfall harvesting systems and $\mathrm{NM}$ tended to quadratic function (Figure 7 ) with rainfall $(\mathrm{mm})$ variation that showed extreme rainfall ( $\mathrm{mm}$ ) had a negative effect on increasing yield of proso millet under rainfall harvesting system, and three hundred rainfall ( $\mathrm{mm}$ ) of growing season was suitable for rainfall harvesting system in proso millet. Mean increasing rates of yield with rainfall harvesting systems were found significantly linearly correlated with the rainfall $(\mathrm{mm})$ that was explained according to quadratic function (Figure 8) showed that effects of different systems to increase yield of proso millet were limited by abundant rainfall $(\mathrm{mm})$, and $250 \mathrm{~mm}$ rainfall of growing season was appropriate for increasing rate of yield.

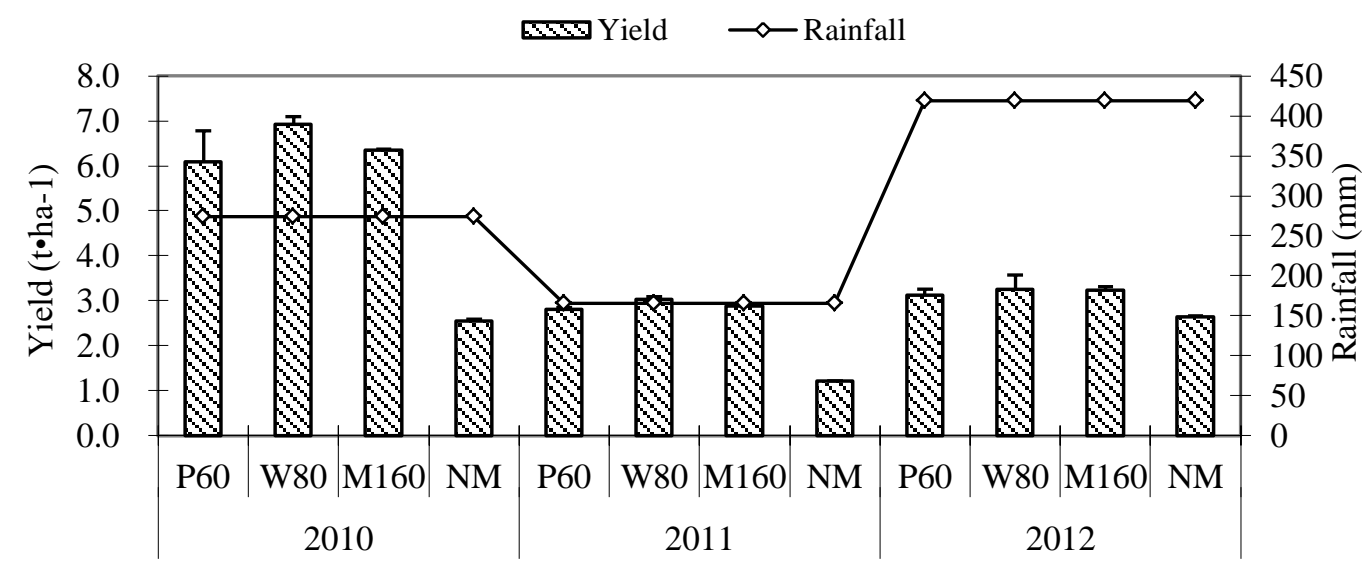

Figure 6. Yields of proso millet and the rainfalls in 2010-2012. W80, the rainwater harvesting practice with $40 \mathrm{~cm}$ wide plastic film mulched W-shaped ridges; M160, the rainwater harvesting practice with $100 \mathrm{~cm}$ wide plastic film mulched M-shaped ridges; P60, the rainwater harvesting practice with $60 \mathrm{~cm}$ wide plastic film mulched ridges; NM, non-mulching plots. 


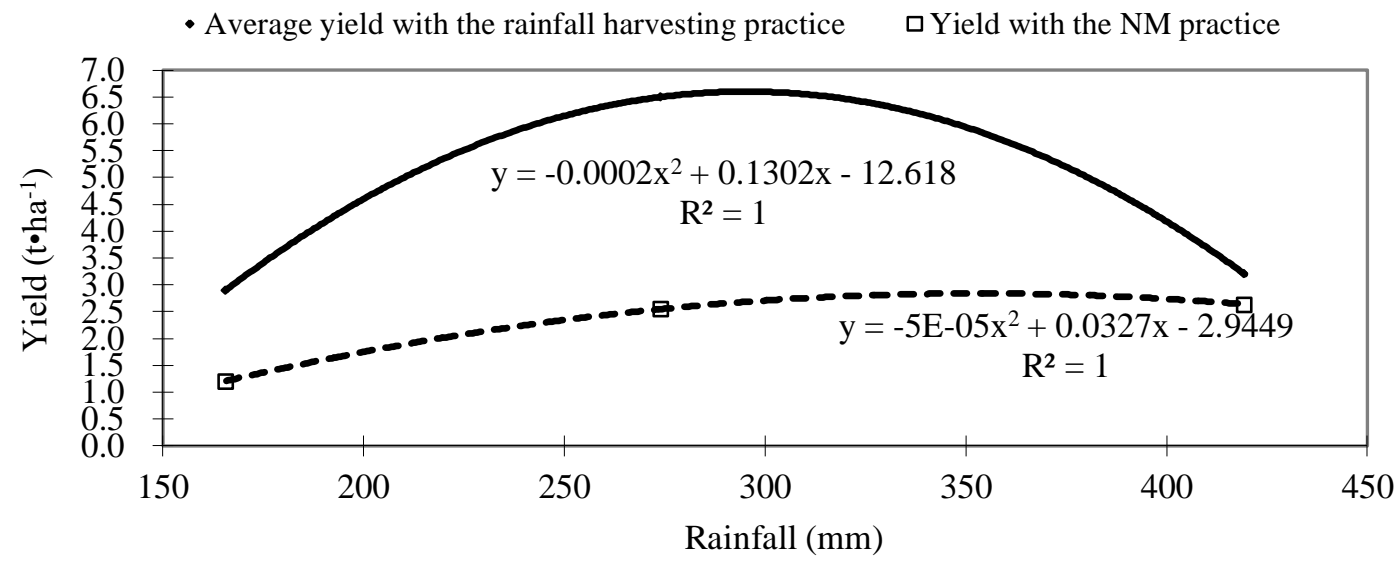

Figure 7. Average yields of proso millet with the different rainwater harvesting and NM practices at the rainfalls (mm). Different rainwater harvesting practices include P60, M160 and W80. W80, the rainwater harvesting practice with $40 \mathrm{~cm}$ wide plastic film mulched W-shaped ridges; M160, the rainwater harvesting practice with $100 \mathrm{~cm}$ wide plastic film mulched M-shaped ridges; P60, the rainwater harvesting practice with $60 \mathrm{~cm}$ wide plastic film mulched ridges; NM, non-mulching plots.

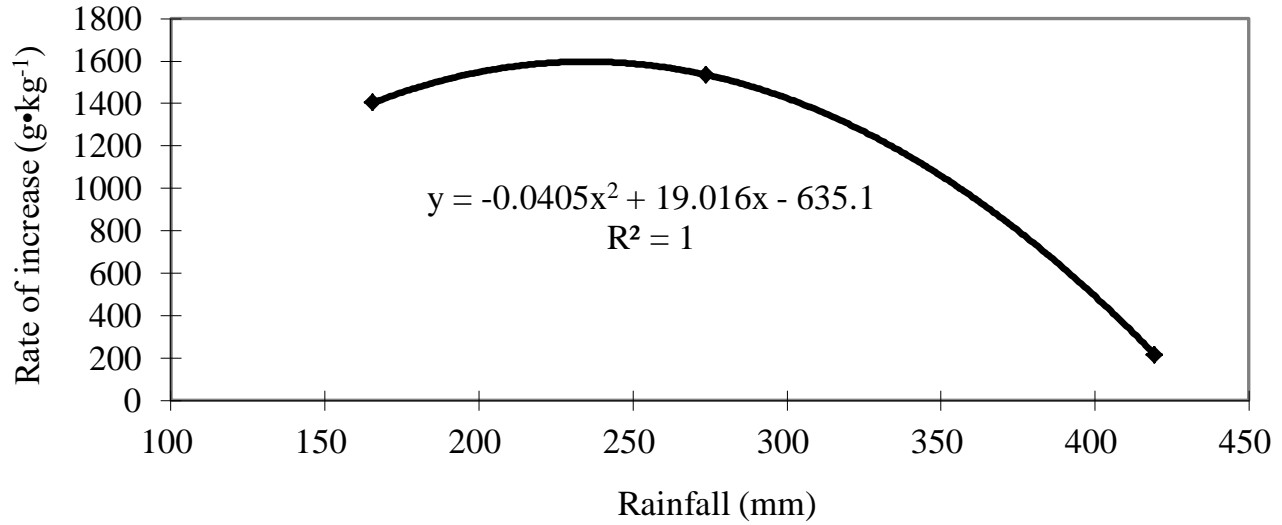

Figure 8. Relations between the mean rates of increase of the yield of proso millet and the rainfalls ( $\mathrm{mm})$.

\section{Discussion}

\section{Water content of topsoil and temperature of topsoil}

Rainfall harvesting systems influenced water content of topsoil and temperature of topsoil and had been suggested as rainfall conservation to improve agricultural productivity where water is scarce for irrigation (J M Miriti et al., 2012). PRFRH system could improve rainfall utilization and increase water content of topsoil and temperature of topsoil (Xianglin Li et al., 2007; Hong et al., 2012). In this study, rainfall harvesting systems could increased water content of topsoil with performing better on $20-40 \mathrm{~cm}$ soil layer than on 0-20 cm soil layer, and increased soil water content at jointing stage more than those at mature stage due to water evaporation which might result from degraded or broken plastic film of later stage. For soil temperature, mean daily soil temperature of $10 \mathrm{~cm}$ soil depth of different systems and NM were always higher than air temperature, and mean daily soil temperature of different systems was higher than those of NM at the measurement-involved stage. These results showed rainfall harvesting systems played an important factor in increasing water content of topsoil and temperature of topsoil (Gao and li, 2005; Xiao et al., 2010; Hong et al., 2012; Wang et al., 2013), and this result supported hypotheses tested. "W-shaped" systems performed best among all rainfall harvesting systems.

3.2 Growth stage with best performances of the rainfall harvesting systems

High water content of topsoil and temperature of topsoil were necessary for seed germination and crop growth (Gelmond, 1978; Li et al., 1999; Luan et al., 2001). Rainfall harvesting systems increased water content of topsoil and temperature of topsoil, which are sufficient advantage for improving proso millet growth. In this study, increase rates of plant height of rainfall harvesting systems at jointing stage were higher than those at mature stage. Rainfall harvesting systems, therefore, probably had better effects on improving early growth of proso millet than later growth. In this regard, potato was researched and to obtain similar results (Hong et al., 2012 and Xiao et al., 2010).

\section{The optimal rainfall harvesting system}

In arid and semi-arid regions, rainfall harvesting systems based on plastic mulch could increase water content of soil and crop yield (Deng et al., 2006), and there are optimal rainfall harvesting systems for different crops reported in recent years. The optimal rainfall harvesting systems with furrow and plastic film mulched ridges of different crops were $60 \mathrm{~cm}$ wide furrows and $60 \mathrm{~cm}$ wide ridges (maize, alfalfa and millet) (Li and Gong, 2002; Li et al., 2007; Qu et al., 2012) and ones with $45 \mathrm{~cm}$ wide furrows and $60 \mathrm{~cm}$ wide ridges (potato) (Tian et al., 2003). In this study, rainfall harvesting systems increased yield and WUE of proso millet compared with those of NM, and high yield and WUE were found in "W-shaped" systems. Mean rates of yield increase and mean rate of WUE increase with "W-shaped" systems were higher $(P<0.05)$ than those of other systems and NM. "W-shaped" system performed better in increasing water content of topsoil, temperature of topsoil and yield of proso millet than "P60" system. "W-shaped" system was an optimal rainfall harvesting system of proso millet in semi-arid regions, meet objective of this study. 


\section{Limiting factor of rainfall harvesting system}

Rainfall harvesting system has suitable regions and reported to be limited use in regions of less than $250 \mathrm{~mm}$ annual rainfall (Li, 1998; Ben et al., 1987; Boers et al., 1986a, 1986b, 1982). For simulated rainfall conditions, abundant rainfall (mm) limited yield increasing effect of rainfall harvesting practices (Xiao et al., 2008). In this study, lodging of proso millet was found in 2012, which may result from that rainfall was so too many that vegetative growth of proso millet was excessive. Besides, Figure 7 and Figure 8 showed further relationship between rainfall $(\mathrm{mm})$ and yield traits. Figure 8 showed that rainfall harvesting systems performed the best effect on yield of proso millet with about $300 \mathrm{~mm}$ growth rainfall, and it was over $250 \mathrm{~mm}$ rainfall that was found to prevent rainfall harvesting system from increasing the rates of moving up in the yield of proso millet (Figure 7). Yield increasing effects of rainfall harvesting systems, therefore, were limited by abundant rainfall $(\mathrm{mm})$ that was found in maize (Ren et al., 2008) in simulated rainfall conditions and performed the best affection with $250 \mathrm{~mm}-300 \mathrm{~mm}$ rainfall during growing seasons of proso millet in semi-arid regions. Although limiting factor of rainfall harvesting system was found in the field to some extent, further research was still needed due to less test seasons.

\section{Conclusion}

Rainfall harvesting systems based on furrows and plastic film-mulched ridges could increase water content of topsoil, move up in temperature of topsoil, and improve growth, yield and WUE of proso millet, respectively. Abundant rainfall (mm) was a limited factor for increasing rate of yield of proso millet under rainfall harvesting system. Rainfall harvesting systems performed better in improving early growth and yield formation of proso millet. About $250 \mathrm{~mm}-300 \mathrm{~mm}$ rainfall during growing season of proso millet was right for rainfall harvesting system. "W-shaped" system was suitable for increasing yield of proso millet in semi-arid areas.

\section{Acknowledgements}

This work was supported by the Special Fund for Agro-scientific Research in the Public Interest (Project No. 200903007) and National Millet Crops Research and Development System ( Project No. CARS-07-12.5-A9 ).

\section{References}

Ben-Asher, J., Warrick, A.W. (1987). Effect of variations in soil properties and precipitation on microcatchment water balance. Agric. Water Manage. 12(3), 177-194.

Boers, T.M., Ben-Asher, J.A. (1982). Review of rainwater harvesting. Agric. Water Manage. 5, 145-158.

Boers, T.M., De-Groaf, M., Feddes, R.A. (1986b). A linear regression model combined with a soil water balance model to design micro-catchments for water harvesting in arid zones. Agric. Water Manage. 11, 187-206.

Boers, T.M., Zondervan, K., Ben-Asher, J. (1986a). Micro-catchments water harvesting (MCWH) for arid zone development. Agric. Water Manage. 12, 21-39.

Canarache, A., Dumitru, E. (2008). No-till and minimum tillage in Romania. In: Goddard, T., Zoebisch, M., Gan, Y., Ellis, W., Watson, A., Sombatpanit, S. (Eds.), No-Till Farming Systems. WASWC, Thailand, pp. 331-345.

Chen, Y., Liu, S., Li, H., Li, X.F., Song, C.Y., Cruse, R.M., Zhang, X.Y. (2011). Effects of conservation tillage on corn and soybean yield in the humid continental climate region of Northeast China. Soil Till. Res.115-116, 56-61.

Chakraborty, D., Nagarajan, S., Aggarwal, P., Gupta, V.K., Tomar, R.K., Garg, R.N., Sahoo, R.N., Sarkar, A., Chopra, U.K., Sundara Sarma, K.S., Kalra, N. (2008). Effect of mulching on soil and plant water status, and the growth and yield of wheat (Triticum awstivum L.) in a Semiarid environment. Agric. Water Manage. 95, 1323-1334.

Deng, X.P., Shan, L., Zhang, H., Neil, C.Turner. (2006). improving agricultural water use efficiency in arid and semiarid areas of China. Agric. Water Manage. 80, 23-40.

Derpsch, R. (2005). The extent of conservation agriculture adoption worldwide: implications and impact. Paper presented to III World Congress on Conservation Agriculture, Nairobi, Kenya, October 2005. Available from: < www.fao.org/ag/ca/en/www.rolfderpsch.com> (accessed 18.03.11).

Dong, H. Z., Li, W. J., Tang, W., Zhang, D. M. (2009). Early plastic mulching increases stand establishment and lint yield of cotton in saline fields. Field Crop Res. 111, 269-275.

E, Dube., C, Chiduza., P, Muchaonyerwa. (2012). Conservation agriculture effects on soil organic matter on a Haplic Cambisol after four years of maize - oat and maize - grazing vetch rotation in South Africa. Soil Till. Res. 123, 21-28.

Gale, W.J., McColl, R.W., Xiefang. (1993). Sandy fields traditional farming water conservation in China. J.Soil Water Comserv. 48, 474-477.

Gao, Y. J., Li, S. X. (2005). Cause and mechanism of crop yield reduction under straw mulch in dryland. Trans. Chinese Soci. Agric. Engin. $21(7), 15-19$.

Gao, Y. Q., Zhang, G. P., Chen, Z. G., Yan, P. (2008). The innovation of new agriculture technique for drying farming system. Fazhan. Yuedujujiao. 10, 5-6 (in Chinese).

Gelmond, H. (1978). Problems in crop seed germination. In: Gupta, U.S. (Ed.), Crop Physiology. Oxford and IBH, New Delhi. pp, 715.

Hobbs, P.R. (2007). Conservation agriculture (CA), defined as minimal soil disturbance (no-till) and permanent soil cover (mulch) combined with rotations, is a more sustainable cultivation system for the future than those presently practiced. J. Agric. Sci. 145, 127-137.

Hong, Z., You Cai, X., Feng Min, L. (2012). Plastic film mulch for half growing-season maximized WUE and yield of potato via moisture-temperature improvement in a semi-arid agroecosystem. Agric. Water Manage. 104, 68-78.

Hou, X. Y., Wang, F.X., Han, J.J. (2010). Duration of plastic mulch for potato growth under drip irrigation in an arid region of Northwest China. Agri. Forest Meteor. 150, 115-121.

Miriti, J.M., Kironchi, G., Esilaba, A.O. (2012). Yield and water use efficiencies of maize and cowpea as affected cropping systems in semi-arid Eastern kenya. Agric. Water Manage. 115, 148-155.

Jaetzold, R., Schmidt, H., Hornetz, B., Shisanya, C. (2006). Farm management hardbook of Kenya.Natural conditions and farm information, vol. II, Part C1 - East Keny, 2nd edition. Ministry of Agriculture, Kenya.

Jiyang, Z., Jingsheng, S., Aiwang, D. (2007). effects of different planting patterns on water use and yield performance of winter wheat in the Huang-Huai-Hai Plain of China. Agric. Water Manage. 92, 41-47. 
Lal, H., Silva, A.S., Porto, E.R., Costa, A.E.M. (1984). Animal-drawn ridger-blade and its use in a new type of in situ rainwater harvesting. Pesqui. Agropecu. Bras. 19, 1385-1393.

Lampurlanes, J., Angas, P., Cantero-Martinez, C. (2002). Tillage effects on water storage during fallow, and on barley root growth and yield in two contrasting soils of the semi-arid segarra region in Spain. Soil Till. Res. 65, 207-220.

Lafond, G.P., Boyetchko, S.M., Brandt, S.A., Clayton, G.W., Entz, M.H. (1996). Influence of changing tillage practices on crop production. Can. J. Plant Sci. 76, 641-649.

Lenssen, A. W., Johnson, G. D., Carlson, G. R. (2007). Cropping sequence and tillage system influence annual crop production and water use in semiarid Montana, USA. Field Crop Res. 100, 32-43.

Li, F.M., Guo, A.H., Wei, H. (1999). Effects of clear plastic film mulch on yield of spring wheat. Field Crop Res. 63, $79-86$.

Li, F.M., Song, Q.H., Jjemba, P.K., Shi, Y.C. (2004b). Dynamics of soil microbial biomass C and soil fertility in cropland mulched with plastic film in a semiarid agroecosystem. Soil Biol. Biochem. 36, 1893-1902.

Li, F.M., Wang, J., Xu, J.Z., Xu, H.L. (2004a). Productivity and soil response to plastic film mulching durations for spring wheat on entisols in the semiarid Loess Plateau of China. Soil Till. Res. 78, 9-20.

Li, F.M., Yan, X., Wang, J., Li, S.Q., Wang, T.C. (2001). The mechanism of yield decrease of spring wheat resulted from plastic film mulching. Sci. Agricul. Sin. 34 (3), 330-333.

Li, F.R. (1998). Studies on Arid Agricultural Ecosystems. Xi'an: Shaan'xi Science and Technology Press. pp, 57 (in Chinese).

Li, S.X., Wang, Z.H., Li, S.Q., Gao, Y.J., Tian, X.H. (2013). Effect of plastic sheet mulch, wheat straw mulch, and maize growth on water by evaporation in dryland areas of China. Agric. Water Manage. 116, 39-49.

Li, X.L., Su, D.R., Yuan, Q.H. (2007). Ridge-furrow planting of alfalfa (Medicago Sativa L.) for improved rainwater harvest in rainfed semiarid areas in Northwest China. Soil Till. Res. 93, 117-125.

Li, X.Y., Gong, J.D. (2002). Effects of different ridge: furrow ratios and supplemental irrigation on crop production in ridge and furrow rainfall harvesting system with mulches. Agric. Water Manage. 54, 243-254.

Li, X.Y., Gong, J.D., Gao, Q.Z., Li, F.R. (2001). Incorporation of ridge and furrow method of rainfall harvesting with mulching for crop production under semiarid conditions. Agric. Water Manage. 50(3), 173-183.

Li, X.Y., Gong, J.D. (2002). Effects of different ridge: furrow ratios and supplemental irrigation on crop production in ridge and furrow rainfalll harvesting system with mulches. Agric. Water Manage. 54, 243-254.

Li, X.Y., Gong, J.D., Wei, X.H. (2000). In situ rainwater harvesting and gravel mulch combination for corn production in the dry semiarid region of China. J. Arid Environ. 46, 371-382.

Liakatas, A., Clark, J,A., Monteith, J.L. (1986). Measurements of the heat balance under plastic mulches Part I. Radiation balance and soil heat flux. Agr. Forest Meteorol. 36, 227-239.

Liu, C.A., Jin, S.L., Zhou, L.M., Jia, Y., Li, F.M., Xiong,Y.C., Li, X.G. (2009). Effects of plastic film mulch and tillage on maize productivity and soil paramers. Eur. J. Agron. 31, 241-249.

Luan, G.Q., Wang, Y.H., Xie, X.S., Shen, J.Z. (2001). A preliminary study of the clear plastic mulch effect on potato. J. Chinese Potato. 15 (4), 235-236 (in Chinese).

Luis Ibarra-Jiménez, R., Hugo, Lira,S., Luis, A., Valdez, A., Javier, L.D., Río. (2011). Colored plastic mulches affect soil temperature and tuber production of potato. Acta Agriculturae Scandinavica, Section B - Plant Soil Sci. 61 (2), 1651-1913.

Majed, Abu, Zreig., Abdullah, Tamimi. (2011). Field evaluation of sand-ditch water harvesting technique in Jordan. Agric. Water Manage. 98, 1291-1296.

Mahli, S.S., Mumey, G., O'Sullivan, P.A., Harker, K.N. (1988). An economic comparison of barley production under zero and conventional tillage. Soil Till. Res. 11, 159-166.

Modaihsh, A.S., Horton, R., Kirkham, D. (1985). Soil water evaporation suppression by sand mulches. Soil Sci. 139, $357-361$.

Muller, A.,1991. Comportamento termico do solo e do ar em alface. (Lactuca sativa L.) para diferentes tipos de cobertura do solo. Piracicaba. Msc Thesis, Scola Superiorde Agricultura, universidade de sao Paulo. pp, 77

Murungu, F.S., Chiduza, C., Muchaonyerwa, P., Mnkeni, P.N.S. (2010). Mulch effects on soil moisture and nitrogen, weed growth and irrigated maize productivity in a warm-temperate climate of South Africa. Soil Till. Res. 112(1), 58-65.

Musunda, B. (2010). Evaluation of cover crop species for biomass production, weed suppression and maize yields under irrigation in the Eastern Cape Province, South Africa.MSc thesis. University of Fort Hare, South Africa.

Nachtergaele, J., Poesen, J.W., Van Wesemael, B. (1998). Gravel mulching in vineyards of southern Switzerland. Soil Till. Res. 46, 51-59.

Qu, Y., Su, W., Li, C. (2014). Border effect and physiological characteristics of broomcorn millet under film mulching on ridge-furrow for harvesting rainwater model in the semi-arid region of Northern Shaanxi China. Chinese J. App. Eco. 25(3), 776-782 (in Chinese). Qu, Y., Su, W., Zhang, P.P. (2012). Effects of different water harvesting on soil water, growth and yield of the proso millet (Panicum miliaceum L.) in a semiarid region of northwest China . J. Agri. Sci. 4(9), 106-113.

Ramakrishna, A., Tam, H.M., Wani, S.P., Long, T.D. (2006). Effect of mulch on soil temperature, moisture, weed infestation and yield of groundnut in northern Vietnam. Field Crop Res. 95, 115-125.

Ren, X.L., Jia, Z.K., Chen, X.L. (2008). Effects of a rainwater- harvesting furrow/ridge system on spring corn productivity under simulated rainfalls. Acta. Ecologica. Sinica. 28(3), 1006-1015.

Ren, X.L., Jia, Z.K., Han, Q.F. (2007). Effect of ridge and furrow rainfall harvesting planting system on production of summer maizecorn (Zea mays L.) under simulated rainfall conditions in semi-arid areas. Trans. Chinese Soci. Agric. Engin.. 23(10), 45-50. (in Chinese).

Shuhuai, J., Xiaoli, G., Jibao, L., Pengke, W., Jinfeng, G.,Yang, Q., Baili, F. (2012). Effect of different furrow and mulched ridge on water moisture conversation and water saving of spring mung bean planted farmland. J. Agri. Sci. 7(4), 132-140.

Song, Q.H., Li, F.M., Wang, J., Liu, H.S., Li, S.Q. (2002). Effect of various mulching durations with plastic film on soil microbial quantity and plant nutrients of spring wheat field in semi-arid loess plateau of China. Acta. Ecologica. Sinica. 22 (12), $2127-2132$ (in Chinese).

Tian, Y., Derong, Sua, Li, F.M., Li, X.L. (2003). Effect of rainwater harvesting with ridge and furrow on yield of potato in semiarid areas. Field Crop Res. 84, 385-391.

Tolk, J.A., Howell, T.A., Evett, S.R. (1999). Effect of mulch, irrigation, and soil type on water use and yield of maize. Soil Till. Res. 50, 137-147.

Van wesemael, B., Poesen, J., de Figueiredo, T., Govers, G. (1996). Surface roughness evolution of soils containing rock fragments. Earth Surf. Process. Landforms 21, 399-411. 
Wang, C.R., Tian, X.H., Li, S.X. (2004a). Effects of plastic sheet-mulching on ridge for water-harvesting cultivation on WUE and yield of winter wheat. Agric. Sci. China. 37, 208-214.

Wang, F.X., Kang, Y.H., Liu, S.P. (2003). Plastic mulching effects on potato under drip irrigation and furrow irrigation. Chinese J. Eco-Agric. 11 (4), 99-102 (in Chinese).

Wang, Su.,Yan-Ping, Z.,Yang, Q., Xiaoli, G., JianHua, L., BaiLi, F. (2013). Effects of mulching and fertilization on soil moisture and crop productivity of broomcorn millet in the dry farmland of Loess plateau. J. Food. Agric. Environ. 11(3\&4), 872-878.

Wang, Y.J., Xie, Z.K., Malhi, S.S., Vera, C.L., Zhang, Y.B., Wang, J.N. (2009). Effects of rainfall harvesting and mulching technologies on water use efficiency and crop yield in the semi-arid Loess Plateau, China. Agric. Water Manage. 96, $374-382$.

Wang, Y., Xie, Z.K., Li.F., Zhang, Z. (2004). The effect of supplemental irrigation on watermelon (Citrullus lanatus) production in gravel and sand mulched fields in the Loess Plateau of northwest China. Agric. Water Manage. 69, 29-41.

Wang, Y.j., Xie, Z.K., Li, F.m., Zhang, Z.S. (2004b). The effect of supplemental irrigation on watermelon (Citrullus lanatus) production in gravel and sand mulched fields in the Loess Plateau of northwest China. Agric. Water Manage. 69 (1), $29-41$.

Xianglin, L., Derong, S., Qinghua, Y. (2007). Ridge-furrow planting of alfalfa (Medicago sativa L.) for improved rainwater harvest in rainfed semiarid areas in Northwest China. Soil Till. Res. 93, 117-125.

Xiaolong, R., Zhikuan, J., Xiaoli, C. (2008). Rainfall concentration for increasing corn production under semiarid climate. Agric. Water Manage. 95, 1293-1302.

Xie, R., Li, S., Jin, Y., Li, X., Tang, Q., Wang, K., Gao, S. (2008). The trends of crop yield responses to conservation tillage in China. J. Integra. Agr. Res. 41(2), 397-404.

Xie, Z.K., Wang, Y.J., Cheng, G.D., Maihi, S.S., Vera, C.L., Guo, Z.H., Zhang, Y.B. (2010). Particle-size effects on soil temperature, evaporation, water use efficiency and watermelon yield in fields mulched with gravel and sand in semi-arid Loess Plateau of northwest China. Agric. Water Manage. 97, 917-923.

Xie, Z., Wang, Y., Cheng, G., Malhi, S.S., Vera, C.L., Guo, Z., Zhang, Y. (2010). Particle-size effects on soil temperature, evaporation, water use efficiency and watermelon yield in fields mulched with gravel and sand in semi-arid Loess Plateau of northwest China. Agric. Water Manage. 97 (6), 917-923.

Xie, Z., Wang, Y., Jiang, W., Wei, X. (2006). Evaporation and evapotranspiration in a watermelon field mulched with gravel of different sizes in northwest, China. Agric. Water Manage. 81 (1-2), 173-184.

Yajun, W., Zhongkui, X., Sukhdev, S.M., Cecil, L.V., Yubao, Z., Zhihong, G. (2011). Effects of gravel-sand mulch, plastic mulch and ridge and furrow rainfall harvesting system combinations on water use efficiency, soil temperature and watermelon yield in a semiarid Loess Plateau of northwestern China. Agric. Water Manage. 101, 88-92.

Zhang, P.P., Feng, B.L., Wang, P.K., Dai, H.P., Song, H., Gao, X.L., Gao, J.F., Chen, J., Chai, Y. (2012). Leaf senescence and activities of antioxidant enzymes in different broom millet (Panicum miliaceum L. ) cultivars under simulated drought condition. J. Food. Agric. Environ. 10(2), 438-444.

Zhang, S.L., Lars, L., Harald, G., Yanan, T., Xueyun, Y., Quanjiu, W. (2009). Effects of mulching and catch cropping on soil temperature, soil moisture and wheat yield on the Loess Plateau of China. Soil Till. Res. 102, 78-86.

Zhang, X.Y., Chen, S.Y., Liu, M.Y. (2002). Evapotranspiration, yield and crop coefficient of irrigated maize under straw mulch conditions. Pro. Phy. Geo. 21, 583-592.

Zhao, J.B., Mei, X.R., Zhong, Z.Z. (1996). The effect of straw mulch on crop water use efficiency in dryland. Agric. Sci. China. 29, 59-66.

Zhao, S., Li, F., Wang, J. (1995). On the development of water harvesting agriculture in the semiarid area north west China. Acta Bot Boreal Occident Sin. 15(8), 9-13 (in Chinese).

Zhou, L.M., Li, F.M., Jin, S.L., Song, Y.J. (2009). How two ridges and the furrow mulched with plastic film affect soil water, soil temperature and yield of maize on the semiarid Loess Plateau of China. Field Crop Res. 113, 41-47.

Zhu, Q., Wu, F., Jin, Y. (1994). Rainwater harvesting and utilization in Gansu province. J. Gansu Water Resource Techno. 6, 6-11( in Chinese).

Zentner, R.P., Lafond, G.P., Derksen, D.A., Campbell, C.A. (2002). Tillage method and crop diversification: effect on economic returns and riskiness of cropping systems in a Thin Black Chernozem of the Canadian Prairies. Soil Till. Res. 67, 9-21.

Zentner, R.P., Lafond, G.P., Derksen, D.A., Nagy, C.N., Wall, D.D., May, W.E. (2004). Effects of tillage method and crop rotations on non-renewable energy use efficiency for a thin Black Chernozem in the Canadian Prairies. Soil Till. Res. 77, $125-136$.

\section{Citation:}

Yang, Q.U., Feng, B. (2020). Growing Characters of Proso millet (Panicum miliaceum L.) In Response to Different Rainwater Harvesting Practices in Semi-arid Region of the Loess Plateau in China. Ukrainian Journal of Ecology, 10(1), 66-75.

(cc) $\mathrm{EY}$ This work is licensed under a Creative Commons Attribution 4.0. License 